\title{
Dampak Pandemi Covid-19 Terhadap Harga Saham Syariah di Indonesia
}

\author{
Hasya Mazaya Lathifah ${ }^{1)}$, Dewi Santi Febrianti²), Anisa Putri Utami ${ }^{3)}$, Atiqah Athi Ulhaq ${ }^{4)}$, Tulasmi ${ }^{5)}$, \\ Titania Mukti ${ }^{6}$ \\ 1,2,3,4,5,6 Program Studi Ekonomi Islam, Fakultas Ilmu Agama Islam, Universitas Islam Indonesia \\ *Email korespondensi: $18423118 @$ students.uii.ac.id
}

\begin{abstract}
COVID-19 Pandemic has brought several direct impacts in Indonesia to make every sector decrease especially in Capital Market since March 2020. COVID-19 is the main impact that affected to decrease the value of ICI in every sector on the stock exchange. However, there is a sector that seems capable to survive during the Pandemic, which is the consumer goods industry sector. One of the successful sectors coming from the consumer goods industry sector is the pharmacy business sector (INAF and KAEF). The research aims to analyze INAF and KAEF stocks during the Pandemic, whether both stocks can survive or not by using a various approach such as global economy, the impact of foreign and domestic policies, the effect of PSBB (Large-scale Social Restrictions), also the lockdown which being held in March-December. The method that is used is qualitative, as the data were collected from ISE (Indonesia Stock Exchange) and Yahoo Finance. The result of this research shows that INAF and KAEF stocks can survive and highly increase the stock price during the COVID-19 Pandemic.
\end{abstract}

Keywords : Sharia Capital Market, Sharia Stock, Covid-19, BEI, IHSG

Saran sitasi: Lathifah, H. M., Febrianti, D. S., Utami, A. P., Ulhaq, A. A., Tulasmi., \& Mukti, T. (2021). Dampak Pandemi Covid-19 Terhadap Harga Saham Syariah di Indonesia. Jurnal Ilmiah Ekonomi Islam, 7(01), 223-229. doi: http://dx.doi.org/10.29040/jiei.v7i1.1772

DOI: http://dx.doi.org/10.29040/jiei.v7i1.1772

\section{PENDAHULUAN}

Saham syariah merupakah salah satu instrumen investasi yang terdapat di pasar modal syariah. Saham syariah merupakan bukti kepemilikan seorang investor atas suatu perusahaan dalam berbentuk sertifikat dimana prinsip-prinsip di dalamnya tidak bertentangan dengan syariah. Mayoritas penduduk di Indonesia yang beragama Islam menjadikannya sebagai potensi yang besar terhadap perkembangan pasar modal syariah terutama saham syariah. Perkembangan pasar modal syariah di Indonesia sendiri telah terjadi sejak terbitnya reksadana syariah pada tahun 1997. Selanjutnya pada tanggal 3 Juli 2000, BEI dan PT Danareksa Investment Management meluncurkan Jakarta Islamic Index (OJK, n.d.). Saat ini terdapat 3 indeks saham syariah di Bursa Efek Indonesia, yaitu Indeks Saham Syariah Indonesia (ISSI), Jakarta Islamic Index (JII) dan Jakarta Islamic Index 70 (JII70 Index) (BEI, 2021).

Pada tanggal 18 April 2001, untuk pertama kali Dewan Syariah Nasional Majelis Ulama Indonesia
(DSN-MUI) mengeluarkan fatwa yang berkaitan langsung dengan pasar modal, yaitu Fatwa Nomor 20/DSN-MUI/IV/2001 tentang Pedoman Pelaksanan Investasi Untuk Reksa Dana Syariah. Perkembangan selanjutnya adanya kesepahaman antara Bapepam dan DSN-MUI untuk mengembangkan pasar modal berbasis syariah di Indonesia yang dilaksanakan pada 14 Maret 2003.

Pasar modal syariah merupakan bagian dari pasar modal di Indonesia. Dimana transaksi yang terjadi mengikuti perkembangan pasar modal pada umumnya, yang tidak lepas dari adanya risiko dan return yang tidak dapat dipastikan. Terkait hal tersebut, investor muslim yang memiliki prinsipprinsip syariah dalam kegiatan investasinya tentunya harus memiliki pengetahuan yang cukup terkait investasi syariah. Tidak hanya yang terkait dengan obyek investasinya, dalam hal ini instrumen saham, tetapi juga meliputi manajemen aset, manajemen risiko investasi maupun hal-hal yang terkait dengan keabsahan suatu transaksi dari sisi syariahnya. Fatwa 
DSN yang terkait dengan saham syariah yaitu DSNMUI No.40/DSN-MUI/2003 menyatakan bahwa jual beli saham itu diperbolehkan untuk dilakukan namun dilarang jika melakukan hal yang berlawanan seperti ribawi, perjudian, short selling, dan margin (Choirunnisak, 2019).

Harga saham yang selalu berfluktuasi sama seperti halnya komoditas yang dijual pasar barang mengikuti hukum permintaan dan penawaran. Beberapa penelitian yang dilakukan, mengkaitkan perubahan nilai saham dengan kinerja perusahaan. Jika kinerja dari sebuah perusahaan baik maka nilai saham perusahaan tersebut pun akan meningkat. Salah satu alat yang dapat digunakan untuk melihat kinerja sebuah perusahaan adalah laporan keuangan perusahaan tersebut. Perusahaan yang sudah go public atau perusahaan terbuka yang sudah tercatat di bursa memiliki kewajiban untuk mempublikasikan laporan keuangannya minimal setiap tiga bulan sekali. Melalui laporan keuangan yang sudah dipublikasikan tersebut, investor maka dapat melihat kinerja perusahaan tertentu. Laporan keuangan ini menjadi salah satu pertimbangan investor dalam melakukan keputusan investasinya. Jika keuntungan atau laba sebuah perusahaan meningkat maka dapat dikatakan saham yang berasal dari perusahaan tersebut akan menarik minat investor untuk melakukan pembelian yang akan menyebabkan meningkatnya permintaan saham. Hal ini berlaku pada sebaliknya, jika perusahaan mengalami kerugian maka harga saham cenderung menurun (Oktavia, 2018).

Harga saham di pasar modal tidak hanya ditentukan oleh faktor kinerja keuangan perusahaan saja. Dalam Undang-Undang No.8 tahun 1995 tentang Pasar Modal disebutkan bahwa informasi atau fakta penting dan relevan mengenai peristiwa, kejadian atau fakta dapat mempengaruhi harga efek pada bursa efek dan atau keputusan pemodal, calon pemodal atau pihak lainnya yang berkepentingan atas informasi tersebut. Sebuah informasi yang dipublikasikan akan memiliki kandungan informasi atau memberikan pengaruh bagi investor dalam keputusan investasinya. Investor akan memberikan reaksi sesuai dengan analisa yang telah dilakukan dan ekspektasi atas saham tersebut (Tulasmi, 2008). Reaksi investor ini diwujudkan dalam bentuk permintaan dan atau penawaran atas suatu saham. Dan sesuai dengan hukum permintaan dan penawaran tentunya hal tersebut dapat berpengaruh terhadap harga saham.
Pada tanggal 31 Desember 2019, secara resmi WHO telah menerima laporan dari China mengenai awal kasus Covid-19 yang muncul pertama kali di Wuhan. Penyebaran virus tersebut sangat cepat ke berbagai negara termasuk Indonesia pada awal Maret 2020 (NEWS, 2020). Bebagai upaya dilakukan pemerintah Indonesia dalam rangka pencegahan virus tersebut. Diantaranya dengan penerapan protokol kesehatan berupa pelaksanaan physical distancing, penggunaan masker saat bepergian ke luar rumah, meliburkan sekolah, melakukan work from home dan sebagainya. Tidak hanya berdampak pada dunia kesehatan saja, namun juga bagi perekonomian negara, salah satu dampak dari kacaunya perekonomian Indonesia adalah anjloknya IHSG di Bursa Efek Indonesia akibat penjualan secara besarbesaran oleh investor karena kekhawatiran atas virus Corona.

Tetapi saham syariah tetap bisa bertahan walaupun ekonomi sedang anjlok dikarenakan saham syariah memiliki kekuatan transaksi sehingga tetap stabil dan instrumen syariah lebih less volatile. Hasan menyatakan bahwa saham syariah jauh lebih baik dalam menghadapi krisis dan terjadi resesi ekonomi secara dapat dilihat dari sisi pengelolaan dan risiko jika dibandingkan dengan perusahaan lainnya yang menerapkan prinsip konvensional.

Secara umum transaksi saham syariah mengalami peningkatan dan saham konvensional mengalami penurunan di tengah kondisi pandemi saat ini (Siregar, 2020). Seperti pada saham di sektor consumer goods terutama pada bidang farmasi karena disaat seperti ini masyarakat banyak membeli obat yang berdampak kepada beberapa perusahaan farmasi. Saham pada perusahaan farmasi yang mengalami kenaikan yaitu PT Indofarma Tbk. (INAF) dan PT Kimia Farma Tbk. (KAEF) kedua perusahaan ini merupakan anak usaha dari PT Bio Farma. Ternyata saham-saham farmasi ini menguat karena adanya sentimen positif bahwa Bio Farma akan memproduksi 250 juta dosis vaksin dan akan bekerja sama ataupun menggaet INAF dan KAEF dalam mendistribusikan vaksin Covid-19 ini ke berbagai negara.

Berdasarkan latar belakang yang telah dipaparkan di atas dan penelitian yang dilakukan oleh Shelly (2020) yang menyebutkan bahwa salah satu dampak terjadinya covid-19 ialah pada umumnya mampu menurunkan nilai harga saham IHSG dan pada semua sektor pasar modal pada khususnya. Maka penulis ingin mengkaji dampak pandemi Covid-19 
terhadap harga saham pada emiten saham syariah khususnya pada sektor Consumer Goods Industry dengan bidang usaha utama farmasi yaitu saham PT PT Indofarma Tbk (INAF) dan PT Kimia Farma Tbk (KAEF).

\section{METODE PENELITIAN}

Penelitian ini menggunakan metode penelitian kualitatif yaitu metode penelitian yang digunakan untuk meneliti pada kondisi objek yang alamiah, dimana peneliti adalah sebagai instrumen kunci, teknik pengumpulan data dilakukan secara triangulasi (gabungan) analisis data bersifat induktif, dan hasil penelitian kualitatif lebih menekankan makna dari pada generalisasi (Sugiono, 2009). Hasil akhir yang diperoleh dalam penelitian dengan penedekatan kualitatif berupa kesimpulan deskriptif dan tidak menggunakan perhitungan statistik (Nurul Huda, 2019). Pendekatan penelitian ini juga dengan menggunakan pendekatan fenomenologi sebagai untuk memahami kondisi masyarakat pada kondisi tertentu. Fenomena yang terjadi dala hal ini adalah pandemi Covid-19 dan pengaruhnya terhadap kondisi saham.

Data yang diolah dalam penelitian ini dikumpulkan dengan bentuk studi kepustakaan (library research), yaitu penelitian yang dilakukan dengan melakukan pengumpulan data dari buku, jurnal, artikel, majalah maupun sumber internet yang terkait dengan permasalahan penelitian. Data yang diperoleh berupa data sekunder dari sumber internet berupa data harga saham, volume perdagangan, artikel jurnal, buku, maupun artikel ilmiah popular. Sumber internet yang digunakan berupa data dari laman idx.co.id, dan ojk.go.id.

Data yang sudah terkumpul kemudian dianalisis melalui 3 tahap teknik analisis data yaitu reduksi data, penyajian data dan penarikan kesimpulan (Miles \& Huberman, 1992). Reduksi data adalah proses pemilihan, pemusatan perhatian pada penyederhanaan, pengabstrakan dan transformasi data kasar yang muncul dari catatan-catatan tertulis di lapangan. Data yang sudah diperoleh kemudian melalui tahap penyajian data, yaitu menyusun informasi yang diperoleh baik berupa angka, matrik, grafik maupun bagan yang valid dan dapat digunakan untuk penarikan kesimpulan. Langkah selanjutnya adalah proses penarikan kesimpulan dari data-data yang sudah disajikan terkait dengan permasalahan penelitian. Penarikan kesimpulan juga diverifikasi selama periode penelitian.

Saham yang menjadi obyek penelitian ini adalah saham yang termasuk kategori Consumer Goods Industry and Chemicals dan konsisten masuk dalam indeks syariah di BEI selama periode pengamatan. Sampel yang didapatkan adalah saham dari PT Indofarma Tbk (INAF) dan PT Kimia Farma Tbk (KAEF). Periode pengamatan adalah selama 9 bulan yaitu Maret 2020-November 2020.

\section{HASIL DAN PEMBAHASAN}

\subsection{Hasil penelitian}

Analisis mengenai dampak pandemi Covid-19 terhadap harga saham dengan adanya berita yang dikabarkan sudah beredar bahwa telah ditemukannya vaksin serta obat dalam mengatasi virus corona dapat memicu kenaikan harga saham yang cukup tinggi dari sektor kesehatan, salah satunya saham farmasi. PT Indofarma Tbk (INAF) dan PT Kimia Farma Tbk (KAEF) keduanya merupakan anak usaha dari PT Bio Farma terbang melejit mencapai ratusan persen. Terlihat bahwa Covid-19 membawa dampak positif kepada kinerja saham syariah di sektor ini dan sampai saat ini masyarakat sangat membutuhkan produk dari farmasi seperti obat-obatan dan lainnya (CNBC Indonesia, 2020)

Pada awal Maret 2020, walaupun Covid-19 telah memasuki Indonesia, kegiatan perdagangan saham syariah cenderung stabil dan tidak terganggu untuk saham INAF dan KAEF. Tetapi pada tanggal 16 Maret 2020, sejak berlakunya kebijakan work from home oleh pemerintah banyak perusahaan yang menerapkan work from home mengakibatkan kepanikan di antara beberapa masyarakat, terutama pada masyarakat di daerah yang langsung terkena dampak dari Covid-19, bahkan pada hari pertama diberlakukannya work from home, saham INAF dan KAEF hampir tidak terdapat volume perdagangan saham. Midesia (2020) menyatakan bahwa telah terjadi penurunan harga saham oleh kedua emiten tersebut pada keesokan harinya. 


\section{Grafik 1. Pergerakan Harga Saham INAF}

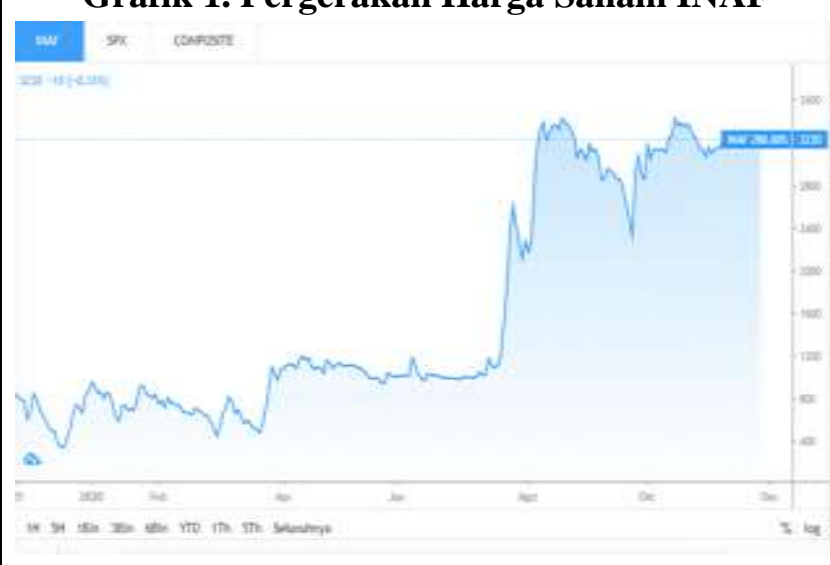

Sumber: investing.com

Harga saham INAF pada tanggal 16 Maret 2020 sebesar Rp 565 lalu turun di hari berikutnya sebesar Rp 530 dan pada tanggal 18 Maret 2020 harganya turun mencapai $\mathrm{Rp}$ 515. Penurunan terjadi dalam beberapa hari saja sampai tanggal 20 Maret 2020 setelah itu melonjak sangat tinggi menjadi $\mathrm{Rp}$ 3.260/saham hingga penutupan perdagangan Jumat, 27 November 2020 sudah naik 277,01\% sejak awal tahun.

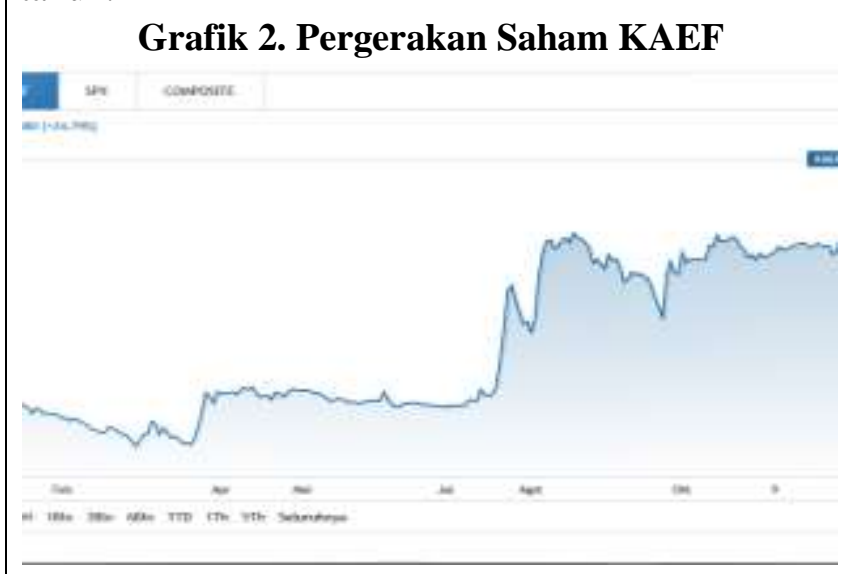

Sumber: investing.com

Terhitung sejak awal tahun, harga saham KAEF telah meningkat sebesar $169,60 \%$. Adapun selama enam bulan terakhir, harga sahamnya naik tajam menjadi $249,22 \%$. Intan (2020) menyatakan bahwa ia tidak merasa heran kepada saham KAEF yang memang menjadi saham yang bergerak di sepanjang tahun 2020 ini. Bursa Efek Indonesia (BEI) menyatakan bahwa KAEF telah membantu menembus 10,2 poin yang berkontribusi langsung terhadap IHSG yang dimana $\mathrm{Rp} 19$ triliun telah disebutkan sebagai kapitalisasi pasar yang telah dicapai.

Tetapi ditemukan serta kedatangan vaksin Covid19 di Indonesia ini tidak hanya berdampak kepada saham yang memang berhubungan langsung dengan kesehatan, tetapi memiliki dampak kepada hal lainnya seperti terhadap saham syariah di sektor lainnya serta perekonomian dan politik di dalam negeri dan luar negeri.

Walaupun sebenarnya kita mengira bahwa hanya karena kedatangan vaksin dapat menyebabkan harga saham farmasi melonjak naik tetapi menurut jurnal (Faktor-Faktor Penyebab Naik Turunnya Harga Saham, Apa Saja? - Cermati.com, n.d.) bahwa naik turunnya harga saham ternyata dapat dipengaruhi dengan adanya kegiatan dari korporasi perusahaan, proyek yang sedang dikerjakan saat itu dan di masa depan, kinerja dari perusahaan itu sendiri, adanya kebijakan dari pemerintah, fundamental dari makro ekonomi serta bagaimana fluktuasi kurs saat itu dari rupiah terhadap mata uang asing tidak lupa juga sentimen-sentimen yang menyebabkan para investor merasa panik. Namun, jika diperhatikan vaksin ini merupakan salah satu proyek di perusahaan tersebut jelas bahwa proyek tersebut berhasil dan membawa sentimen positif terhadap harga saham syariah.

\subsection{Pembahasan}

Melihat langsung pada sektor Consumer Goods Industry and Chemicals yang di dalamnya terdapat emiten dalam melakukan pengolahan untuk mengubah bahan dasar yang tersedia maupun setengah jadi menjadi barang yang jadi yang dapat dikonsumsi oleh pribadi maupun rumah tangga. Untuk bidang usaha pada sektor ini meliputi pharmaceuticals, food and beverages, cosmetics and household, tobacco manufacturers, houseware dan lainnya. Penulis memilih dua perusahaan berdasarkan emiten yang terdapat pada Indeks Saham Syariah Indonesia (ISSI) pada sektor Consumer Goods Industry and Chemicals dengan bidang usaha utama terkait farmasi yaitu:

Tabel 1. Saham Syariah Sektor Consumer Goods Industry

\begin{tabular}{cccc}
\hline No. & Kode & Nama Emiten & $\begin{array}{c}\text { Bidang Usaha } \\
\text { Utama }\end{array}$ \\
\hline 1. & INAF & Indofarma Tbk & Farmasi \\
\hline 2. & KAEF & $\begin{array}{l}\text { Kimia Farma } \\
\text { (Persero) Tbk }\end{array}$ & Farmasi \\
\hline
\end{tabular}

Setelah mengamati bahwa COVID-19 tanpa disadari membawa dampak yang positif kepada emiten di sektor Consumer Goods Industry. Karena 
terlihat pada situasi seperti ini masyarakat sangat membutuhkan stok obat-obatan yang dimana karena diberlakukannya work from home dan social distancing menyebabkan masyarakat akan mengurangi aktivitas diluar rumah sehingga mereka akan lebih memperbanyak stok sebelum diberlakukan kedua peraturan tersebut.

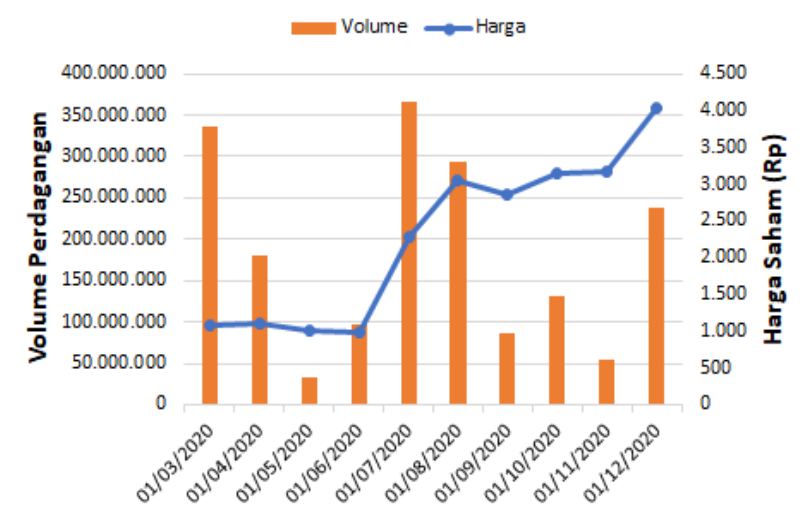

Grafik 3. Harga dan Volume Perdagangan Saham INAF

Sumber: Yahoo Finance

Berdasarkan Grafik 3, untuk saham INAF penurunan terjadi pada 1 Mei 2020 dari bulan sebelumnya sebesar Rp 100. Untuk selisih harga pada awal bulan Maret-Desember mengalami gain sebesar Rp 2.950. Terlihat bahwa kinerja pada saham INAF terjadi peningkatan karena di masa pandemi ini obatobatan lebih banyak dikonsumsi oleh masyarakat jika dibandingkan dengan sebelumnya pandemi COVID19 serta pengadaan vaksin COVID-19 yang dipercepat.

\section{Grafik 4. Harga dan Volume Saham KAEF}

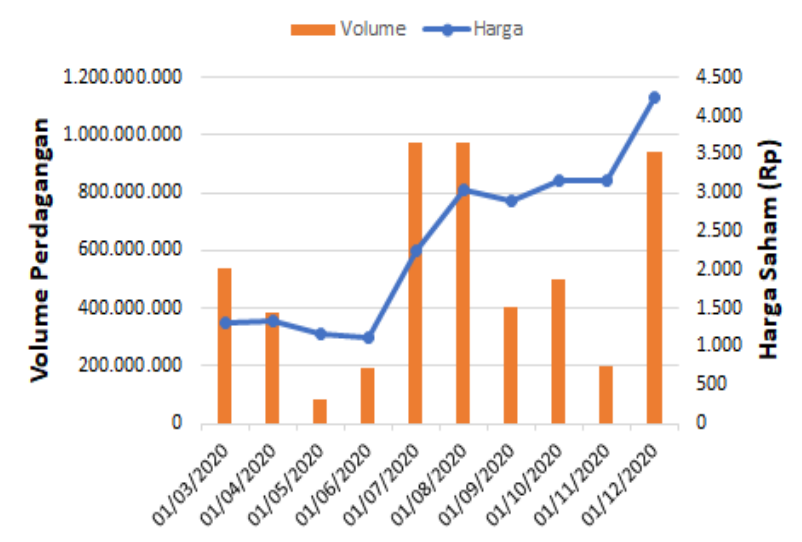

Sumber: Yahoo Finance

Berdasarkan Grafik 4, untuk saham KAEF penurunan terjadi pada 1 Juni 2020 dari bulan sebelumnya sebesar Rp 40. Untuk selisih harga pada awal bulan Maret-Desember mengalami gain sebesar
Rp 2.940. Terlihat bahwa kinerja pada saham KAEF terjadi peningkatan karena di masa pandemi ini obatobatan lebih banyak dikonsumsi oleh masyarakat jika dibandingkan dengan sebelumnya pandemi Covid-19.

Kenaikan saham INAF ini juga disebutkan oleh Direktur Utama PT Indofarma Tbk Arief Pramuhanto bahwa perseroan mempunyai berbagai alat mulai dari rapid test antibodi dan antigen, PCR test serta perangkat yang dapat melindungi diri seperti APD dan masker. Manajemen INAF sendiri menyatakan bahwa proyeksi mereka akan membuat pendapatan dari berbagai produk yang memang memiliki kesamaan fungsi akan menghasilkan kontribusi yang besar di tahun depan.

Melihat kembali ketika diterapkan PSBB ternyata membuat adanya pelarangan untuk beroperasi di perkantoran dan berbagai industri dalam waktu yang cukup lama sehingga menyebabkan kerugian dalam bidang ekonomi. IHSG sempat anjlok hingga 5,1\% ke level 4.891 dengan diterapkannya PSBB Jilid 2 di DKI Jakarta. Mas'udi dan Winanti (2020) menyatakan bahwa Covid-19 ini membuat berbagai peluang yang ada menjadi melemah untuk masyarakat dalam menghasilkan pendapatan sampai terjadinya hingga 1.943 .916 dari 114.340 perusahaan. Wakil Ketua Perhimpunan Hotel dan Restoran Indonesia (PHRI) yaitu Maulana Yusran menambahkan bawah sektor yang paling banyak terkena PHK berasal dari hotel dan restoran dikarenakan keduanya bisnis utama yang sudah pasti merasakan dampak dari PSBB langsung. Dari sinilah awal mulai penghasilan masyarakat menurun dan membuat aktivitas ekonomi menjadi terbatas. Ternyata bukan hanya negara Indonesia saja yang mengalami penurunan dikarenakan pademi ini tetapi ekonomi di berbagai negara Asia Pasifik juga mengalaminya seperti negara Hong Kong, Singapura, Jepang, Korea Selatan, Thailand, dan Australia karena penyebaran yang semakin meluas (Sebayang, 2020).

Pada pendekatan sektor ekonomi, ternyata sektor politik yang berasal dari luar negeri juga berpengaruh seperti Laksono menyatakan bahwa hasil pemilihan Presiden Amerika Serikat membawa dorongan kepada IHSG. Piter (2020) menyatakan jika Trump memenangkan pemilihan presiden maka memberikan dampak kepada negatif kepada Indonesia walaupun dampak yang didapatkan tidak terlalu signifikan. Sedangkan, jika Biden memenangkannya maka ekonomi politik yang selama ini panas akan mereda. Walaupun sebenarnya dapat dilihat untuk jangka 
waktu panjang perekonomian Indonesia dapat ditentukan dan dipengaruhi oleh kita sendiri. Tetapi akhirnya terlihat bahwa Joe Biden yang terpilih menjadi Presiden selanjutnya yang memang berdampak kepada IHSG Indonesia walaupun tidak berlangsung lama.

Memang di waktu-waktu seperti pandemi ini ramai sekali diperbincangkan karena rata-rata harga saham mengalami penurunan yang dimana sebab salah satunya adalah sebagian dari pemegang saham telah menjual sahamnya karena mereka berpikiran khawatir untuk kedepannya apakah saham-saham tersebut akan lebih turun nilainya. Seharusnya di momentum seperti inilah Saraswati (2020) menyatakan bahwa investor dapat memanfaatkannya karena memiliki peluang dalam membeli saham dengan harga ketika turun. Karena sebenarnya bisa saja kondisi seperti ini tidak akan selamanya tetapi hanya sementara.

Tetapi dengan adanya saham syariah yang menekankan bahwa lebih stabil dibandingkan dengan saham konvensional ini telah terbukti oleh saham dari INAF dan KAEF. Hebatnya lagi saham syariah ini lebih less volatile. Walaupun nilai harga saham syariah tidak akan selalu naik terus-menerus karena memang pergerakannya fluktuatif dan banyak faktor serta sentimen lainnya yang dapat mempengaruhi nilai harga saham tersebut.

\section{KESIMPULAN}

Setelah pandemi Covid-19 memasuki Indonesia pada Maret 2020 semua sektor mengalami penurunan ditambah dengan diterapkannya work from home dan lock down untuk upaya mengurangi penyebaran Covid-19. Ternyata menyebabkan sektor ekonomi dan berbagai sektor lainnya mengalami penurunan yang tajam terlebih lagi pada sektor pasar modal yang berdampak kepada nilai IHSG. Tetapi setelah mengamati kedua saham yang berasal dari sektor consumer goods industry terutama dalam bidang farmasi ternyata mengalami kenaikan yaitu pada saham INAF dan KAEF. Kedua saham itu mengalami peningkatan nilai saham dikarenakan lebih banyak masyarakat yang mengkonsumsi obat-obatan disaat pandemi Covid-19 ini jika dibandingkan dengan sebelum pandemi ini terjadi.

Ternyata bukan sentimen itu saja yang membuat kedua saham itu mengalami kenaikan, tetapi setelah kabar beredar di masyarakat bahwa ditemukannya vaksin serta obat untuk virus Covid-19 membuat harga saham INAF dan KAEF langsung mengalami kenaikan yang tinggi sampai saham INAF mengalami suspend beberapa hari karena tingginya kenaikan dalam sehari. Terbukti bahwa saham syariah tetap bisa bertahan di tengah ekonomi yang sedang anjlok akibat Covid-19. Hal ini dikarenakan saham syariah memiliki kekuatan transaksi sehingga tetap stabil dan instrumen syariah yang lebih less volatile.

Pendekatan lain yang membuat kedua harga saham ini mengalami pergerakan berasal dari sektor ekonomi dengan melihat kepada kebijakan pemerintah mengenai diterapkannya PSBB membuat adanya pelarangan adanya operasi perkantoran dan berbagai industri dalam waktu yang cukup lama sehingga menyebabkan kerugian dalam bidang ekonomi. Banyak tenaga kerja yang terkena PHK sehingga menurunnya tingkat pendapatan masyarakat dan membuat aktivitas ekonomi terbatas. Sektor politik yang juga berpengaruh pada nilai IHSG yang disebabkan hasil pemilihan Presiden Amerika Serikat. Terlihat pada Joe Biden yang terpilih menjadi presiden selanjutnya yang berdampak pada IHSG di Indonesia walaupun tidak berlangsung lama.

Waktu pandemi seperti ini rata-rata harga saham mengalami penurunan yang salah satunya disebabkan karena pemegang saham yang telah menjual sahamnya karena khawatir saham-saham tersebut kedepannya nilainya akan turun. Adanya saham syariah menekankan bahwa mereka lebih stabil daripada saham konvensional yang terbukti pada saham INAF dan KAEF. Walaupun nilai harga saham tidak selalu naik karena bersifat fluktuatif dan terdapat faktor-faktor lainnya yang juga mempengaruhi nilai harga saham.

Pengadaan vaksin dari perusahaan biotekonoligi Novavax Inc. juga berpengaruh kepada kedua saham ini. Jadi, pemerintah harus berupaya semaksimal mungkin untuk mempercepat pengadaan vaksin COVID-19 ini dengan melakukan kerja sama dengan negara Tiongkok dan Inggris. Untuk penelitian selanjutnya bisa meneliti bagaimana pergerakan saham INAF dan KAEF ketika masa pandemi sudah berakhir apakah mengalami kenaikan, stabil atau penurunan.

\section{UCAPAN TERIMA KASIH}

Dengan selesainya penulisan artikel ini, penulis anggota dari kelompok B menyampaikan rasa terima kasih banyak kepada seluruh pihak terutama Ibu Tulasmi, SEI., MEI selaku dosen dan Titania Mukti, 
S.E selaku asisten dosen Mata Kuliah Institusi Keuangan Non Bank yang telah membimbing, memberikan motivasi, membantu melakukan pembenahan dan penyempurnaan karya tulis ilmiah ini. Terima kasih juga kepada anggota kelompok yang telah bekerjasama dalam proses penyusunan artikel ini. Penulis memohon maaf apabila terdapat kekurangan ataupun kesalahan dalam proses penyusunan artikel. Semoga artikel ini dapat memberikan kemanfaatan bagi yang membacanya dan memberikan kontribusi yang baik bagi perkembangan ilmu pengetahuan.

\section{REFERENSI}

BEI. (2021). BEI: Indeks Saham Syariah. Diambil kembali dari Indonesian Stock Exchange: https://www.idx.co.id

Chotib, E., \& Huda, N. (2019). Analisis Pengaruh Variabel Ekonomi Makro terhadap Indeks Saham Syariah Indonesia (ISSI) periode 2016 - 2019. Journal of Economics and Business Aseanomics (JEBA), 20.

Hadiwardoyo, W. (2020). Kerugian Ekonomi Nasional Akibat Pandemi Covid-19. Baskara : Journal of Business and Entrepreneurship Volume 2 No. 2 April 2020, 10.

Herdady, M. R. (2020). COVID-19: Alarm Bagi Sistem Rantai Pasok Industri Farmasi. Majalah Farmasetika, 10.

Hindayani, N. (2020). Analisis Reaksi Pasar Saham atas Peristiwa Covid-19 Di Indonesia. JIMEA | Jurnal Ilmiah MEA (Manajemen, Ekonomi, dan Akuntansi), 17.

Ismanto, J. (2020). Reaksi Pasar Modal Terhadap Pengumuman PSBB DKI Jakarta Jilid II ( Event Study LQ-45 Terdaftar BEI ). JURNAL Edueco, 16.
Junaedi, D. (2020). Dampak Pandemi Covid-19 Terhadap Pasar Modal Di Indonesia. Al-Kharaj : Jurnal Ekonomi, Keuangan \& Bisnis Syariah, 11. Kusno, F. (2020). Krisis Politik Ekonomi Global Dampak Pandemi Covid-19. Anterior Jurnal, 9.

Miles, \& Huberman. (1992). Analisis Data Kualitatif. Jakarta: Universitas Indonesia Press.

Muzakki, F. (2020). The Global Political Economy Impact Of Covid-19 And The Implication To Indonesia '. Journal of Social Political Sciences, 18.

OJK. (t.thn.). OJK: Pasar Modal Syariah. Diambil kembali dari Otoritas Jasa Keuangan: https://www.ojk.go.id/

Oktavia, I., \& S.N, K. G. (2019). Faktor-Faktor Yang Mempengaruhi Harga Saham. Sinergitas Quadruple Helix: e-Business dan Fintech sebagai Daya Dorong Pertumbuhan Ekonomi Lokal, 9.

Rizali, A. (2020). Eksistensi Dan Strategi Pengembangan Saham Syariah Di Masa Pandemi Covid-19. Jurnal Ekonomi Islam, 13.

Sugiono. (2009). Memahami Penelitian Kualitatif. Bandung: Alfabeta.

Tulasmi. (2008). Analisis Reaksi Pasar Terhadap Publikasi Perusahaan Yang Dinilai Berdasarkan Prinsip Good Corporate Governance (Studi Pada Bursa Efek Jakarta). UIN Sunan Kalijaga . Yogyakarta: skripsi, tidak dipublikasikan.

Wajdi, M. B., Kuswandi, I., Faruq, U. A., Zulhijra, Khairudin, \& Khoiriyah STAI. (2020). Education Policy Overcome Coronavirus, A Study of Indonesians. EDUTEC : Journal of Education and Technology, 11.

Yamali, F. R., \& Putri, R. N. (2020). Dampak Covid19 Terhadap Ekonomi Indonesia. Ekonomis: Journal of Economics and Business, 5. 